\section{AT LEAST ONE ZOONOSIS SILENTLY SPREADS DURING COVID-19: BRUCELLOSIS}

\section{To the Editors:}

Brucellosis dates back to when humans began herding goats and several reasons account for its re-emergence today. First is underestimation stemming from the erroneous notion that brucellosis was brought under control in the last century. Second is underestimation of the role that goats and goat products play in the chain of transmission to humans. And finally is the failure to consider biofilm phenotypes in research assessing Brucella spp.-ecosystem interactions. Thus, false results are derived, the illness's chronicity increases along with the corresponding failures in antibiotic therapies, and measures more apt to control the disease are simply not adopted.[1]

For the last 60 to 70 years in fact, many zoonotic diseases have simply been undervalued. Ironically, COVID-19 now plays a role in further sidelining them, as the challenges it poses to humanity rivet attention in one direction. However, this shouldn't keep us from preparing ourselves, aware that in the pandemic's shadow, old zoonotic threats, even some with similar symptoms, may be gaining ground and can even be lethal. A first step is to assess these in their true dimensions.[2] In the case of brucellosis, while 500,000 cases are reported globally, this is certainly an inexact figure.[1]

In this vein, it is important to consider Brucella spp. in its abiotic and biotic environments: as bacterial biofilms.[3,4] Although its planktonic forms cause the acute phase of disease, it is the biofilm phenotype that is expressed in the ever more frequent chronic cases. This phenotype is also responsible for antibiotic-resistant cases and other therapy failures associated with this zoonotic disease. Adopting such an understanding facilitates addressing the illness with alternatives aimed at inhibiting, destroying or at least minimizing biofilm formation.[1]

It is useful to note that $90 \%$ of the world's over one billion goats are concentrated in the poorest countries, adding another element of bias when assessing the global impact of this zoonotic disease and often of others, not to mention the associated lack of resources for diagnosis. Goats are small ruminants and excellent reservoirs of $B$. melitensis, the most virulent brucellosis strain in humans, a fact that should not be destined to the same fate of underestimation as has the impact of the disease itself.[5]

\section{REFERENCES}

1. Barreto Argilagos G, Rodríguez Torrens H, Barreto Rodríguez H. Brucelosis, aspectos que limitan su justa valoración. Artículo reseña. Rev Salud Animal [Internet]. 2021 Jan-Apr [cited 2021 Apr 24];43(1):1-7. Available at http://revis tas.censa.edu.cu/index.php/RSA/article/view/1138/1784. Spanish

2. Barreto Argilagos G, Rodríguez Torrens H, Barreto Rodríguez H. Cinco elementos limitan una aproximación al comportamiento real de la leptospirosis. Artículo Especial. Zootecnia Tropical [Internet]. 2020 [cited 2021 Apr 24];38:111. DOI: $10.5281 /$ zenodo.4283614. Available at: http://www.publicaciones.inia .gob.ve/index.php/zootecniatropical/article/view/485. Spanish.

3. Barreto Argilagos G, Rodríguez Torrens H, Barreto Rodríguez H. Brucellosis accompanies humanity into the 21 st century, one element contributes to its persistence particularly. Corpus J Vet Dairy Sci. 2021 Jan 14;2(1):1017.

4. Tang T, Chen G, Guo A, Xu Y, Zhao L, Wan M. Comparative proteomic and genomic analyses of Brucella abortus biofilm and planktonic cells. Mol Med Rep [Internet]. 2020 Feb [cited 2021 Apr 24];21(2):731-43. Available at: https://www.spandidos-publications.com/10.3892/mmr.2019.10888

5. Barreto Argilagos G, Rodríguez Torrens HC, Barreto Rodríguez HC. Brucelosis, aspectos que limitan la aproximación real a esta zoonosis; papel de las cabras. Rev Producción Animal [Internet]. 2020 Aug 25 [cited 2021 Apr 24];32(3). Available at: https://revistas.reduc.edu.cu/index.php/rpa/article/view/ e3536. Spanish.

Guillermo Antonio Barreto-Argilagos PhD (guillermo.barreto@reduc .edu.cu), microbiologist with a doctorate in veterinary sciences, Faculty of Applied Sciences, Ignacio Agramonte Loynaz University, Camagüey, Cuba. https://orcid/0000-0002-0963-0733

Herlinda de la Caridad Rodríguez-Torrens DVM MS, doctor of veterinary medicine with a master's degree in veterinary clinical diagnostics, Veterinary Medicine Department, Faculty of Agriculture, Ignacio Agramonte Loynaz University, Camagüey, Cuba. https://orcid/0000-0002-1964-6640

Submitted: June 18, 2021

Disclosures: None

Accepted for publication: July 4, 2021 